J. Lake Sci. (湖泊科学), 2017, 29(1): 59-68

DOI 10. 18307/2017. 0107

(C) 2017 by Journal of Lake Sciences

\title{
滇池水体不同形态磷负荷时空分布特征”
}

\author{
余佑金 ${ }^{1,2,3,4}$, 方向京 ${ }^{2}$,王圣瑞 ${ }^{3,4}$, 张 荵 $^{3,4}$,焦立新 ${ }^{3,4 * *}$,李 乐 $^{3,4}$,汪学华 ${ }^{1}$ \\ (1:西南林业大学环境科学与工程学院,昆明 650224) \\ (2:云南省林业科学院, 昆明 650204) \\ (3: 中国环境科学研究院环境基准与风险评估国家重点实验室,北京 100012) \\ (4: 中国环境科学研究院国家环境保护湖泊污染控制重点实验室,湖泊生态环境创新基地,北京 100012)
}

\begin{abstract}
摘 要: 利用 ArcGIS 空间插值的方法,通过 2013 年逐月监测 (12 个月) 36 个站点水量及不同形态磷浓度,揭示滇池水体 磷浓度和磷负荷的时空变化, 并探讨不同形态磷负荷的组成贡献, 旨在为进一步实施滇池水污染治理及污染负荷控制提 供依据. 结果表明: 滇池水体总磷 ( TP) 浓度在 $0.13 \sim 0.46 \mathrm{mg} / \mathrm{L}$ 之间, 其中颗粒态磷 (PP) 浓度占 TP 浓度的 $72.6 \%$, 溶解性 活性磷 (SRP) 浓度占 TP 浓度的 $12.8 \%$, 溶解性有机磷 (DOP) 浓度占 TP 浓度的 14\%; 2013 年水体 TP 负荷为 $251 \mathrm{t} / \mathrm{a}$, 其中 PP 负荷为 $190 \mathrm{t} / \mathrm{a}, \mathrm{SRP}$ 负荷为 $26 \mathrm{t} / \mathrm{a}$, DOP 负荷为 $34 \mathrm{t} / \mathrm{a}$; 滇池水体 PP 负荷对 TP 负荷的贡献最大, 为 $76 \%$, 其次为 DOP 和 SRP, 贡献分别为 $13 \%$ 和 $10 \%$; TP 及不同形态磷浓度与其负荷在季节分布上差异显著, 负荷随季节变化呈现秋、冬季 较高, 春、夏季较低, 而浓度呈现夏、秋季较高, 冬、春季相对较低的趋势. 定量评估滇池水体不同形态磷负荷及其组成贡 献,对进一步揭示滇池藻源和泥源内负荷对水污染的贡献具有重要意义.
\end{abstract}

关键词 : 滇池;磷负荷;时空变化;贡献

\section{Spatial and temporal distribution patterns of loadings of different phosphorous forms in Lake Dianchi}

YU Youjin ${ }^{1,2,3,4}$, FANG Xiangjing ${ }^{2}$, WANG Shengrui ${ }^{3,4}$, ZHANG Rui ${ }^{3,4}$, JIAO Lixin ${ }^{3,4 * *}$, LI Le \& $^{3,4}$ \& WANG Xuehua ${ }^{1}$

(1: College of Environmental Science and Engineering, Southwest Forestry University, Kunming 650224, P.R. China)

(2: Yunnan Academy of Forestry, Kunming 650204, P.R. China)

(3: State Key Laboratory of Environmental Criteria and Risk Assessment, Chinese Research Academy of Environmental Sciences, Beijing 100012, P.R.China)

(4: Research Center of Lake Eco-Environment, State Environmental Protection Key Laboratory for Lake Pollution Control, Chinese Research Academy of Environmental Sciences, Beijing 100012, P.R.China)

Abstract: With the help of GIS spatial interpolation, based on the monthly observed data of water yield and phosphorous (P) concentrations in 36 sampling sites in Lake Dianchi, the loading contributions of different $\mathrm{P}$ forms was explored and the spatial and temporal patterns of the $\mathrm{P}$ concentrations and loadings were revealed in this paper, aiming at providing evidence for water pollution treatment and inner loading control. The results showed: The changes in total phosphorus (TP) concentrations in the water ranged between 0.13 and $0.64 \mathrm{mg} / \mathrm{L}$, among which particulate phosphorus (PP) covered 72.6\%, soluble reactive phosphorus (SRP) $12.8 \%$, and dissolved organic phosphorus (DOP) 14\%. During 2013 the average annual TP loading was $251 \mathrm{t} / \mathrm{a}$, among PP loading 190 t/a, SRP 26 t/a, and DOP 34 t/a. TP loading in Lake Dianchi was mostly contributed by PP loading, averaging 76\%, and secondly by DOP and SRP, averaging $10 \%$ and $13 \%$, respectively. There was a significant difference in seasonal distributions in TP concentrations and loadings and in different $\mathrm{P}$ forms. The concentration was characterized with a higher value in summer and autumn in contrast to a relatively low value in winter and spring, while the loading was characterized with a higher value in autumn

* 国家自然科学基金项目( U1202235) 和国家水体污染控制与治理科技重大专项(2012ZX07102-004) 联合资助. 2015 12-14 收稿;2016-04-19 收修改稿. 余佑金(1977 ), 女,硕士研究生;E-mail :yuyoujin98@ 163.com.

** 通信作者; E-mail:jiaolx@ craes.org.cn. 
and winter in contrast to that in spring and summer. Thus, to quantitatively assess the loading of PP and SRP as well as their contributions to TP, was of great importance in guiding the control over the inner loading in Lake Dianchi.

Keywords: Lake Dianchi; phosphorous loading; temporal and spatial changes; contribution

水体富营养化是我国湖泊、水库及近海水域面临的严峻的环境问题, 是氮、磷过剩引起的水体缺氧和水 生生物大量死亡, 甚至出现蓝藻水华的现象. 水体富营养化带来的重大经济损失和流域文化驻足均引起了 社会各界的广泛关注 ${ }^{[1-2]}$. 水体氮、磷来源主要包括外源输人和内源释放两部分. 外源输人主要包括流域周 边工、农业废水和生活污水的直接排放, 种植业和养殖业等农业面源污染输人, 以及大气干湿沉降的人湖 氮、磷污染负荷等 ${ }^{[3]}$; 内源释放主要为湖泊沉积物中氮、磷累积性污染在一定环境条件下持续释放进人水 体 ${ }^{[4]}$, 污染严重的沉积物营养盐持续释放将会使湖泊富营养化时间延长 $30 \sim 40 \mathrm{a}^{[5]}$. 因此, 对于富营养化湖 泊水体治理,在严格控制外源输人的同时, 对于内源释放的风险要加以重视 ${ }^{[6-8]}$.

滇池是云南面积最大的高原淡水湖泊, 也是我国重度富营养化湖泊之一. 近年来, 滇池周边的污染企业 和城市生活污水治理成效显著, 水质恶化的趋势得到了有效控制 ${ }^{[9-10]}$. 尽管如此, 由于滇池地处云南高原断 裂带, 独特的地质构造形成了其特殊的水文过程, 即人湖河流较多, 出湖河流较少, “纳污吐清” 特征明显 ${ }^{[11]}$. 长期的氮、磷累积性污染导致滇池内源污染释放逐年放大, 沉积物内源污染释放在较长时间内、一定程度上 将持续影响湖泊水质,进而导致水体富营养化 ${ }^{[12]}$. 水体氮、磷浓度及其存在形式是湖泊内源污染释放的主 要体现, 也是沉积物一水界面氮、磷交换的基础 ${ }^{[13]}$. 通常情况下, 沉积物和上覆水营养盐交换处于动态平衡 状态, 沉积物一水界面氮磷释放取决于间隙水和上覆水的营养盐浓度梯度, 当间隙水营养盐浓度高于上覆水 时,氮、磷释放特征明显, 反之则吸附特征明显. 因此, 揭示滇池水体氮、磷赋存形态及其时空变化, 是深人阐 明沉积物内源负荷的前提和基础. 以往研究多关注水体氮、磷浓度及水质指标和富营养化评价等方面, 而有 关水体氮、磷负荷的评估尚未见到相关报道. 本研究通过揭示滇池水体不同磷形态浓度的时空分布特征, 并 通过 ArcGIS 空间插值计算面积的方法, 分析了滇池不同湖区水体中不同磷形态的负荷及全湖不同磷形态的 负荷. 通过本项研究, 可评估不同磷形态的负荷及其对总磷 ( TP) 的贡献, 为进一步揭示滇池藻源和泥源内



图 1 滇池水体采样点分布

Fig.1 Distributions of sampling sites in Lake Dianchi
负荷对水污染贡献提供依据.

\section{1 材料与分析}

\section{1 样品采集}

根据滇池地理环境及湖水流向特征,于 2013 年在 滇池选取 36 个采样站点, 其中草海 4 个、外海北部 15 个、外海中部 6 个、外海南部 11 个(图 1). 每月中旬 15 号左右在每个站点分上、中、下 3 层采集水样 (共 12 次), 每层采 $1 \mathrm{~L}$ 水样, 分别装人聚乙烯塑料瓶, 在 $-4^{\circ} \mathrm{C}$ 的环境下冷冻保存待测.

\section{2 样品测定方法及数据统计分析}

TP 采用过硫酸钾氧化-紫外分光光度计法测定. 溶解性活性磷 (SRP)、溶解性总磷 (DTP) 用过膜水体 采用紫外分光光度计法测定. 溶解性有机磷 (DOP) 等 于 DTP 与 SRP 的差值, 颗粒态磷 $(\mathrm{PP})$ 等于 TP 与 DTP 的差值.

数据分析及制图采用 Origin 8.5 和 ArcGIS 10.0 软 件. 根据不同站点水体磷浓度和水深数据, 通过 ArcGIS 10.0 软件空间差值计算得到相应站点涉及的 水域面积,进而得到滇池不同湖区水体 TP 及不同形 态磷负荷, 方法见文献 [14-16], 计算公式为: 


$$
L=\sum_{i=1}^{n}\left(C_{i} \cdot H_{i} \cdot S_{i}\right)
$$

式中, $L$ 为滇池水体磷负荷 $(\mathrm{t}) ; S_{i}$ 为根据磷浓度和水深空间差值获得的水域面积 $\left(\mathrm{km}^{2}\right) ; H_{i}$ 为第 $i$ 个站点涉 及的水深 $(\mathrm{m}) ; C_{i}$ 为第 $i$ 个站点的磷浓度 $(\mathrm{mg} / \mathrm{L}), i$ 为采样点位编号.

\section{2 结果与讨论}

\section{1 滇池水体不同形态磷浓度的时空变化}

全湖 36 个站点水体 TP 浓度在 $0.13 \sim 0.46 \mathrm{mg} / \mathrm{L}$ 之间, 平均值为 $0.19 \mathrm{mg} / \mathrm{L}$; 各形态磷中, PP 浓度最高, 在 $0.098 \sim 0.32 \mathrm{mg} / \mathrm{L}$ 之间, 平均值为 $0.14 \mathrm{mg} / \mathrm{L}$, 占 TP 浓度的 $72.6 \%$; 其次是 $\mathrm{DOP}$, 在 $0.014 \sim 0.11 \mathrm{mg} / \mathrm{L}$ 之 间, 平均值为 $0.03 \mathrm{mg} / \mathrm{L}$, 占 TP 浓度的 $14 \%, \mathrm{SRP}$ 浓度最低, 在 $0.01 \sim 0.099 \mathrm{mg} / \mathrm{L}$ 之间, 平均值为 $0.02 \mathrm{mg} / \mathrm{L}$, 占 TP 浓度的 $12.8 \%$. TP 、PP、DOP 浓度以外海北部广谱大沟河人湖口附近最高, 其次为草海中部和和外海 南部古城河人湖口附近, 外海中部相对较低; SRP 浓度以草海中部以及外海北部盘龙江人湖口处最高, 其次 是外海北部广谱大沟河人湖口附近, 外海中部和外海南部相对较低 (图 2). 总体上, TP 及不同形态磷的分布 呈现随水流方向由北向南逐渐降低的趋势, 到外海南部后随水流又呈上升趋势. 利用 SPSS 软件对 36 个站 点的 TP、SRP、PP、DOP 浓度进行数据分析 (除外海北部盘龙江人湖口处 SRP), 水体 TP 与 SRP、PP、DOP 浓 度均呈显著正相关 $\left(0.817^{* * *}>r>0.606^{* * *}, P<0.05, n=36\right)$, 这表明当 TP 浓度增加时, 不同形态磷浓度相应增 加, 不同形态磷间维持某种动态平衡.

水体 TP 及不同形态磷的空间分布特征可反映污染物的来源及输人途径, 同时不同形态磷浓度空间分 布的差异对进一步揭示水污染特征具有重要意义. 滇池水体中的 TP、PP、DOP 浓度高值区域主要集中在外 海北部广谱大沟河人湖口附近, 其原因是广谱大沟河是途径斗南花海基地的主要河流,2014 年以前斗南是 昆明市鲜花、蔬菜种植基地, 鲜花、蔬菜种植是当地人民经济收人主要来源之一 ${ }^{[17]}$, 化肥过度使用经雨水及 农业用水等方式排人滇池 ${ }^{[18]}$; 其次外海北岸是滇池主要人湖河流的集中分布区域, 主要接受盘龙江、宝象河 等较大河流污染输人, 近年来发展起来的城市群体是滇池外海北部污染物输人的主要来源 ${ }^{[19-20]}$. TP、PP、 DOP 浓度在草海出现高值是因为草海湖区输人河渠西坝河、马龙河等人湖河流途经昆明主城区, 大量主城 区的生活污水和工业企业废水随河水汇集流人草海, 因此不同形态磷浓度较高 ${ }^{[21]}$, 相关研究表明草海汇聚 昆明主城区 $38 \%$ 工厂废水以及居民日常的生活污水 ${ }^{[22]}$. 同时 TP、PP、DOP 浓度在外海南部古城河人湖口附 近出现次高值与昆阳磷矿厂的污水排放是分不开的, 外加该区域含有磷矿石, 经地表风化后随雨水冲刷进 人湖区. 外海中部新街、马金铺一带远离各污染源, 因此 TP 及不同形态磷浓度相对较低.

滇池水体不同月份 TP 浓度在 $0.15 \sim 0.26 \mathrm{mg} / \mathrm{L}$ 之间变化, 其中 SRP 浓度在 $0.008 \sim 0.048 \mathrm{mg} / \mathrm{L}$ 之间变 化, PP 浓度在 $0.12 \sim 0.21 \mathrm{mg} / \mathrm{L}$ 之间变化, DOP 浓度在 $0.017 \sim 0.054 \mathrm{mg} / \mathrm{L}$ 之间变化. 滇池水体 TP 及不同形 态磷浓度呈现夏、秋季较高, 冬、春季相对较低的趋势 (图 3). 其中 DOP、SRP 尤为突出, DOP 浓度峰值出现 在 9 月和 10 月, 低值出现在 2 月和 4 月, SRP 浓度峰值出现在 6 月和 10 月, 低值出现在 2 月; 而 TP、PP 浓度 在季节变化上起伏稍平缓, 高值出现在 7 月. 滇池一年内干湿季节分明, $87.9 \%$ 的年降雨集中在 5-10 月 ${ }^{[23]}$, 夏、秋季自然降水量大, 受到雨水淋溶作用, 城市生活污水、农田养分及水土流失的磷养分随地表径流 汇集进人滇池 ${ }^{[24]}$, 使得在雨水充足的夏、秋季节, 水体中的磷浓度较高, 与大气降水呈正相关. 12 个月的 TP、SRP、PP 和 DOP 浓度数据统计分析表明, 水体中 TP 和 SRP 浓度均呈显著正相关 $\left(r=0.737^{* *}, P=0.05\right.$, $n=12)$. SRP 是能直接被植物吸收利用的磷, 对湖泊初级生产力具有重要的影响, TP 与 SRP 浓度在季节变 化上呈现出很好的正相关性, 表明 TP 浓度在某种程度上直接影响湖泊初级生产力, 夏季外源污染输人提高 蓝藻暴发的风险.

\section{2 滇池水体不同形态磷负荷的时空变化}

根据滇池 2013 年逐月 (12 个月) 监测 36 个站点水量及不同形态磷浓度数据分析得到滇池水体 TP 负荷 为 $251 \mathrm{t} / \mathrm{a}$, 其中 PP 负荷占比最高, 为 $190 \mathrm{t} / \mathrm{a}$; 其次 DOP, 为 $34 \mathrm{t} / \mathrm{a}$; SRP 负荷最低, 为 $26 \mathrm{t} / \mathrm{a}$. 滇池水体 TP 及 不同形态磷负荷的空间分布为, TP、DOP、PP 负荷高值的区域主要分布在外海北部广谱大沟河人湖口附近, 并以该站点向其他湖区逐渐扩散, 草海及外海南岸负荷均较低. SRP 负荷高值分布在外海北部盘龙江人湖 

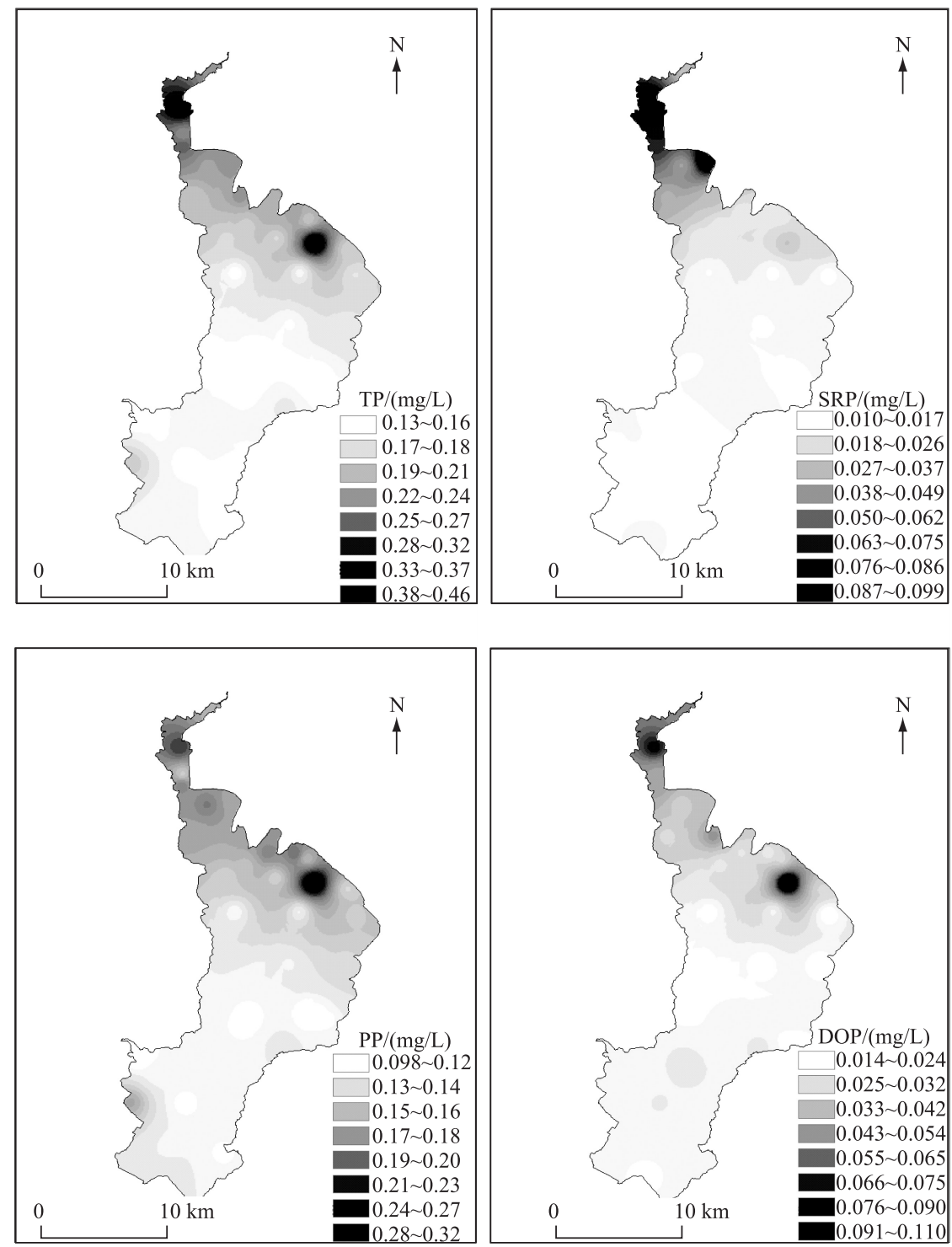

图 2 滇池水体 TP 及不同形态磷浓度的空间变化

Fig.2 Spatial changes in concentrations of TP and different $\mathrm{P}$ forms in the water of Lake Dianchi

口处和草海中部,在水流方向上呈现出逐渐降低的趋势 (图 4).

滇池全湖磷负荷分布主要受水深、磷浓度及外源输人分布三重因素影响. 滇池流域长年盛行西南风, 导 致在外海北部形成局部环流 ${ }^{[25]}$, 在主风向长时间的作用下, 浮游植物由西向东南逐渐汇集到外海北部浅水 区域, 外海北部浅水植物对浮游植物有截留作用, 形成外海北部藻源性的磷污染, 同时由于外海北部区域水 深较浅, 沉积物中较轻的物质在风浪的作用下再次悬浮, DOP 主要来源于浮游动物的排泄物, 是一种极不容 易被微生物吸收利用的磷素形态, PP 是颗粒态磷素形态, 不能被植物直接吸收利用, SRP 是能被浅水植物 和浮游植物直接吸收利用的磷素形态, 因而形成 TP、DOP 和 PP 在外海北部湖滨带出现负荷高值, 而 SRP 不 明显的现象. 外海中部区域沿河流方向出现磷负荷的集中态势, 这与滇池流域的地形、降雨、水流、水深等多 种环境因素有关, 湖心水体深度为 $5 \mathrm{~m}$ 以上 ${ }^{[26]}$, 水量大, 是导致 TP、DOP、PP 负荷出现集中的主要原因. SRP 
负荷高值分布在外海北部盘龙江人湖口处和 草海中部,表明昆明主城区河道污染物的输 人对滇池湖泊磷的污染有一定的贡献. 36 个 站点的 TP、SRP、PP、DOP 负荷数据分析发 现, 水体 TP 与 PP 负荷呈显著正相关 $(r=$ $\left.0.9566^{* *}, P=0.00, n=36\right)$, PP 负荷对 TP 负荷 贡献率达到 76\%, 远超出 DOP 与 SRP 的贡 献,原因之一是 PP 是吸附在固体表面或者固 体内部的颗粒磷形态, 不易被植物吸收利用, 长年游离在水体中 ${ }^{[27]}$; 其次是滇池水体恶 化,微生物群落减少, 不能将 PP 完全矿化成 植物能吸收利用的溶解态 ${ }^{[28]}$; 再者滇池湖面 上风浪较大, 风速在 $2.1 \sim 6.8 \mathrm{~m} / \mathrm{s}$ 之间, 使得 滇池底泥中的沉积物颗粒悬浮 ${ }^{[29]}$, 由于 PP 悬浮在水体中生物有效性不高 ${ }^{[30]}$, 因此滞留 在水体中;三种原因导致 PP 为 TP 负荷贡献 源, 而 TP 与 DOP 负荷呈显著正相关 $(r=$ $\left.0.911^{* *}, P=0.00, n=36\right)$, 原因还有待于进一 步探索. 外海南部和草海 TP 及不同形态磷负 荷较低, 是因为南部有大量的林地, 能截留和 降解水体中的磷污染物质, 从而有效减少污 染物对滇池的输人,而草海是因为水深较浅, 且草海环境水量是滇池水体的 $1.3 \%{ }^{[31]}$, 所

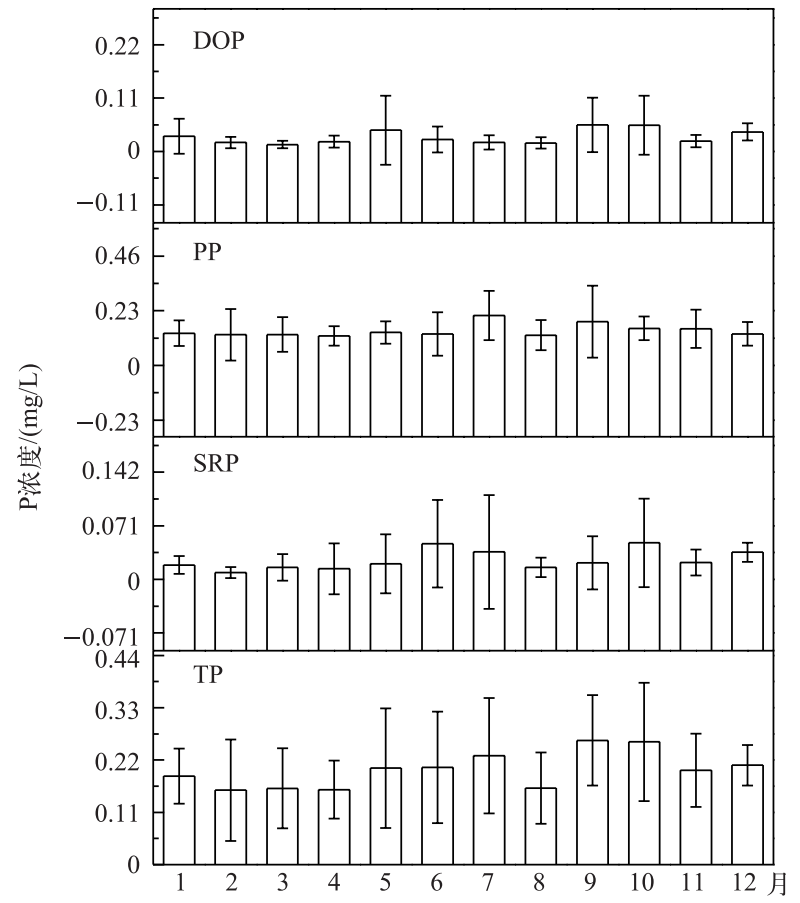

图 3 滇池 12 个月不同形态磷的浓度变化

Fig. 3 Monthly changes in concentrations of different $\mathrm{P}$ forms in the water of Lake Dianchi 以,呈现出水体中磷负荷较低的现象.

TP 及不同形态磷负荷随季节变化差异明显, 总体上呈现秋、冬季高, 春、夏季低, TP 与 PP 负荷呈显著 正相关 $\left(r=0.791^{* *}, P=0.02, n=12\right)$, 而 TP 与 SRP、DOP 负荷无明显相关性, 这与滇池地形地貌、流域风 速、浮游植物生长与死亡的影响密不可分; SRP、DOP 负荷季节波动较大, SRP 负荷高值出现在 11 和 12 月, 秋、冬季 SRP 负荷占全年负荷的 $62 \%, \mathrm{DOP}$ 高值出现 $9 、 10$ 和 12 月,占全年负荷的 $56 \%$, 低值出现在 3 和 4 月 (图 5). 滇池是重度富营养化湖泊, 蓝藻水华年年暴发, 春、夏季为蓝藻生长和暴发集中时期, 蓝藻大量吸 收水体磷营养盐, 使得 SRP 负荷明显降低, 到了秋、冬季, 蓝藻大量死亡分解, 死体中磷营养盐被微生物分解 释放, 提高水体中 SRP 负荷 ${ }^{[32]}$, 因此蓝藻生长死亡是磷负荷随季节变化的重要原因之一 ${ }^{[33]}$.

\section{3 滇池水体磷形态的组成及其对 TP 的贡献}

滇池水体 PP 负荷对 TP 负荷的贡献最大, 在 55\% 85\% 之间变化, 占 TP 负荷的 76\%, 其次为 DOP, 占 $\mathrm{TP}$ 负荷的 13\%; SRP 对 TP 负荷的贡献相对较低, 占 TP 负荷的 10\%. 滇池不同磷形态负荷对 TP 贡献分布特 征为, SRP 负荷对 TP 负荷贡献高值主要分布在盘龙江人口处和草海, 而 PP 负荷贡献高值主要分布在外海 湖泊各个河流人湖口处及外海中部地区, 草海相对较低, DOP 负荷贡献高值则主要分布在草海和外海北部 广谱大沟河人湖口附近 (图 6).

滇池进行环湖截污措施后, 草海湖区相对封闭, 水流速度慢、水深较浅, 仅有少量耐污染植物生长, PP 是因吸附作用存在于固体表面或内部的颗粒磷形态, 粒径大的颗粒态 PP 进人后极易滞留沉积进人底泥, 粒 径小的溶解性 SRP 和 DOP 滞留在水体中, 因此 PP 负荷贡献在草海出现低值, 而 SRP 和 DOP 在此出现高 值. 外海水域面积宽, 水量大, 全湖 $\mathrm{pH}$ 值在 7.0 8.5 之间, 平均温度为 $14.7^{\circ} \mathrm{C}^{[34]}$, 就目前的理化指标而言, 有 利于水体中的磷矿化, 促进动植物生长繁衍, 吸收大量 SRP 磷素形态, 使得外海各站点 SRP 负荷对 TP 负荷 贡献明显降低. 而 PP 负荷贡献高值主要分布外海河流人湖口及湖湾, 表明湖湾及人湖口附近的浅水植物对 浮游植物有截留作用, 因而造成 PP 对 TP 负荷的贡献在外海湖泊各个河流人湖口处及湖滨带出现高值, 而 



图 4 滇池水体 TP 及不同形态磷负荷的空间变化

Fig.4 Spatial changes in loadings of TP and different P forms in the water of Lake Dianchi

其他区域贡献较低. 外海中部出现 PP 负荷贡献高值,原因有待于进一步探索.

不同形态磷每个月的负荷对 TP 负荷贡献的差异明显, 不同月份 PP 负荷贡献率在 $64 \% \sim 86 \%$ 之间变 化, 可见, 滇池全年以 PP 负荷贡献为主, 最高值出现在 8 月, 最低值出现在 12 月; SRP 负荷贡献在 4\% 17\% 之间变化, 最高值主要出现在冬季 12 月, 最低值则出现在 4 月; DOP 负荷贡献在 $5 \% \sim 22 \%$ 之间变化, 最高值 出现在夏季的 9 月, 最低值出现在 3 月 (图 7). PP 虽然不能被生物直接吸收利用, 但从长远来看, 会对水体 富营养化有一定的贡献 ${ }^{[35]}$, 且 PP 受微生物环境影响非常大. SRP 与 DOP 负荷贡献全年变化趋势一致, 呈 逐渐上升趋势, 而 PP 负荷贡献呈逐渐下降态势. 这说明, 在春、夏季 PP 有部分被微生物分解转化为 SRP 和 $\mathrm{DOP}$, 这可能与春、夏季气温回升、微生物大量繁衍及活动加剧有关 ${ }^{[36]}$, 因此 PP 与 SRP、DOP 之间形成一定 的平衡效应.

从负荷贡献来看, PP 负荷占 TP 负荷的 $76 \%$, 是 DOP 的 5.8 倍、SRP 的 7.6 倍, 有相关研究表明, 磷营养 


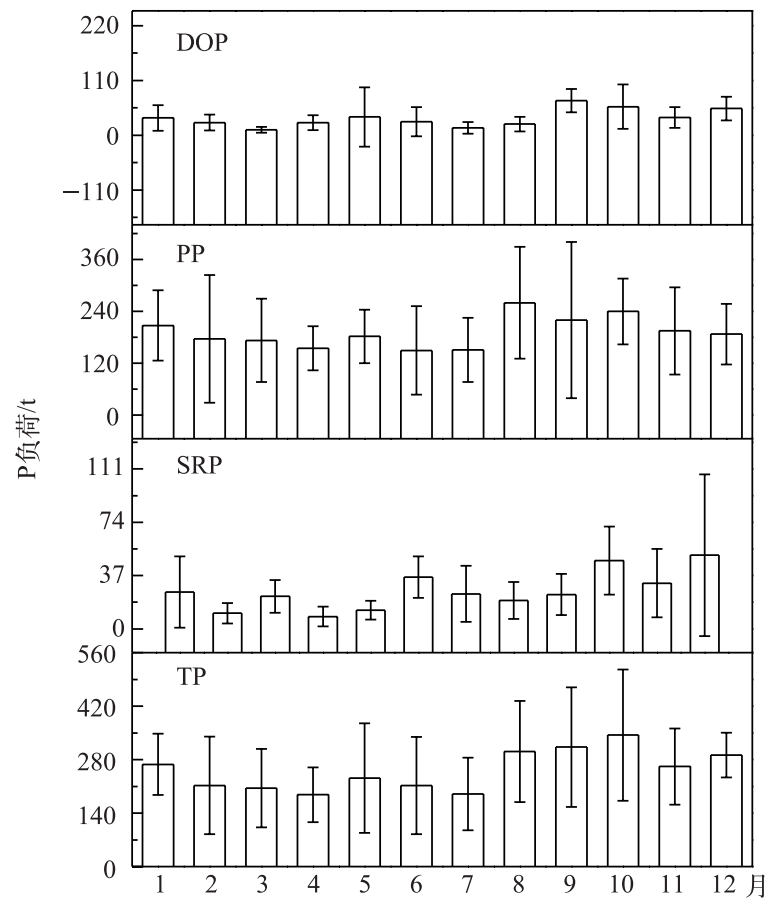

图 5 滇池 12 个月不同形态磷的负荷变化

Fig.5 Monthly changes in loadings of different $\mathrm{P}$ forms in the water of Lake Dianchi
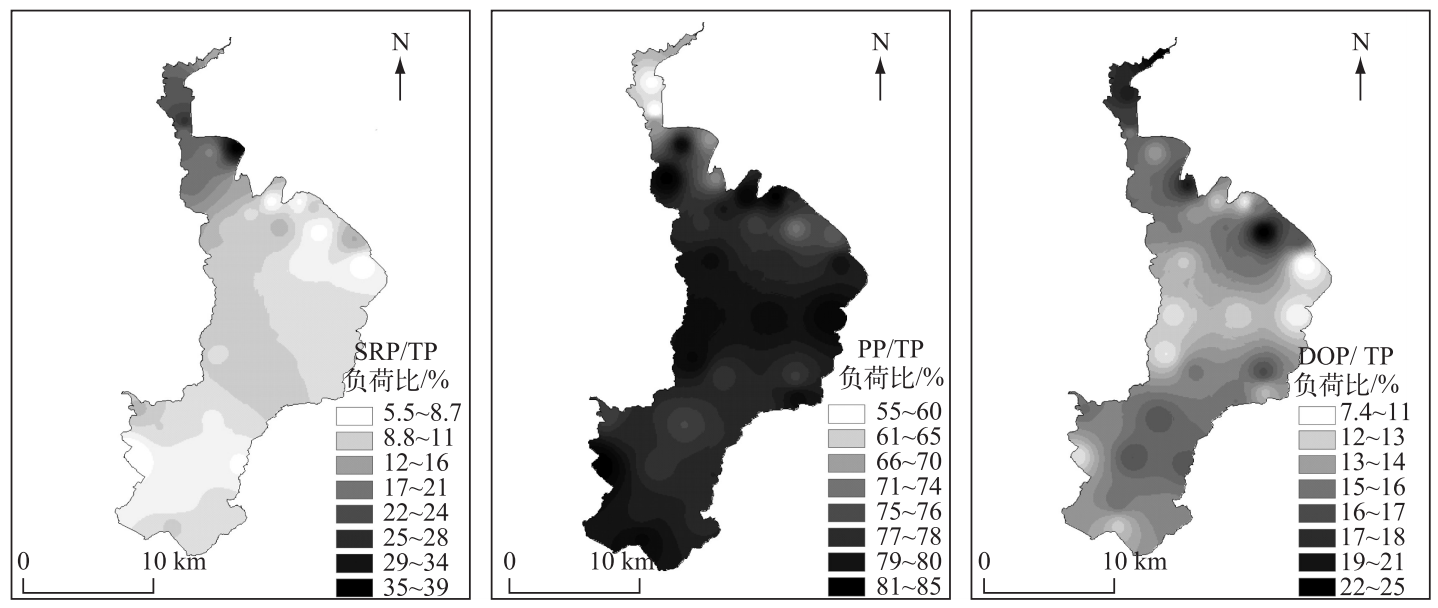

图 6 滇池水体不同形态磷负荷对 TP 负荷贡献的空间分布

Fig.6 Loading contributions of different P forms to TP in the water of Lake Dianchi

盐输人负荷在逐年增加, 成为影响水质的主要因素 ${ }^{[37]}$, 控制外源 PP 对湖泊水体的输人及内源 PP 释放能有 效降低水体的污染程度. 解决外源 PP 输人主要依赖于植树造林、减少城市规模化、净化工业废水、减少生活 废水排人 ${ }^{[38]}$; 解决内源释放可以立足于原位覆盖技术和异位疏浚技术. 


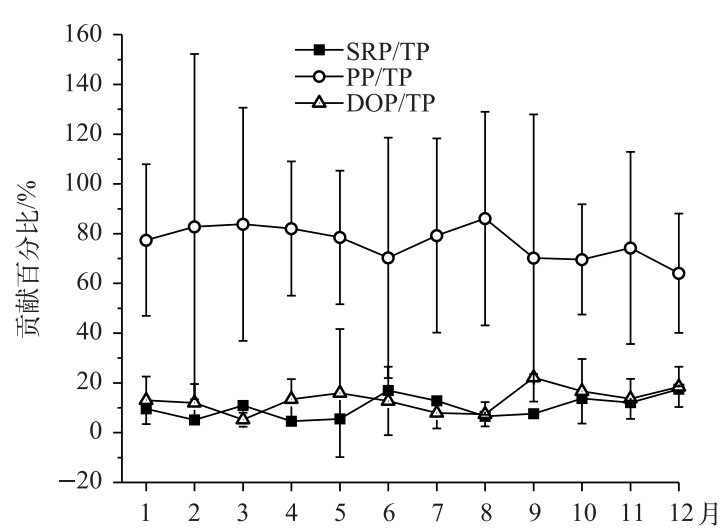

图 7 滇池水体不同磷形态负荷贡献的月变化

Fig. 7 Monthly changes in loading contributions of different $\mathrm{P}$ forms in the water of Lake Dianchi

\section{3 结论}

1) 滇池水体 TP、PP、DOP 和 SRP 浓度分别在 $0.13 \sim 0.46 、 0.098 \sim 0.32 、 0.014 \sim 0.11$ 和 $0.01 \sim 0.099$ $\mathrm{mg} / \mathrm{L}$ 之间, PP、DOP 和 SRP 全湖浓度平均值分别 占 TP 浓度平均值的 $72.6 \% 、 14 \%$ 和 $12.8 \%$. TP 及 不同形态磷浓度的分布呈现随水流方向逐渐降低 随后升高的趋势. TP 及不同形态磷浓度空间分布 上有差异, 此差异由外源污染输人量、滇池地形及 水文特征、沉积物特点、人类经济社会活动等因素 共同决定.

2) 2013 年滇池水体 TP、PP、DOP 和 SRP 负荷 分别为 $251 、 190 、 34$ 和 $26 \mathrm{t} / \mathrm{a}$, 其中 TP、DOP 和 PP 负荷高值的区域主要分布在外海北部广谱大沟河 人湖口附近, 并以该站点向其他湖区逐渐扩散. 而 SRP 高值区域分布在外海北部盘龙江人湖口处和

草海中部. TP 及不同形态磷负荷分布主要受水深、磷浓度及外源输人分布三重因素影响.

3) TP 及不同形态磷浓度与其负荷在季节分布上差异显著. TP 及不同形态磷浓度呈现夏、秋季较高, 冬、春季相对较低的趋势, 而 TP 及不同形态磷负荷呈秋、冬季节高, 春、夏季节低的趋势. 这主要是夏季雨量 充沛, 水土流失的磷养分随地表径流汇集进人滇池, 以及蓝藻的生长死亡规律使得磷负荷与磷浓度在季节 分布上出现差异.

4 ) 滇池水体 PP 负荷占 TP 负荷的 76\%, 是 DOP 贡献的 5.8 倍、SRP 的 7.6 倍. 全年以 PP 负荷贡献为 主, PP 不能被生物直接吸收利用, 但从长远来看, 会对水体富营养化有一定的贡献, 因此控制外源及内源 PP 对湖泊水体的输人能一定程度上降低水体的富营养化程度.

致谢: 感谢中国环境科学研究院环境基准与风险评估国家重点实验室的刘文斌、汪氷、徐元志等在写作期间 给予我细心的指导和关心, 同时对在云南民族大学实验室中给予我帮助的同学及实验人员一并致谢.

\section{4 参考文献}

[ 1 ] Howarth RW, Boyer EW, Pabich WJ et al. Nitrogen use in the United States from 1961-2000 and potential future trends. Ambio A Journal of the Human Environment, 2002, 31(2) : 88-96.

[ 2 ] Huang HB, Gao Y, Cao JJ et al. Non-point source pollution of nitrogen in ground water in urban agricultural region of Shanghai and risk assessment. Journal of Soil and Water Conservation, 2010, 24(3) : 56-59, 70.

[ 3 ] Squizzato S, Masiol M. Application of meteorology-based methods to determine local and external contributions to particulate matter pollution: A case study in Venice (Italy). Atmospheric Environment, 2015, 119: 69-81.

[ 4 ] Gubelit Y, Polyak Y, Dembska G et al. Nutrient and metal pollution of the eastern Gulf of Finland coastline: Sediments, macroalgae, microbiota. Science of the Total Environment, 2016, 550: 806-819.

[ 5 ] Murphy T, Lawson A, Kumagai M et al. Release of phosphorus from sediments in Lake Biwa. Limnology, 2001, 2(2): 119-128.

[ 6 ] Li Yiping, Pang Yong, Xiang Jun. Analysis to the characteristics of temporal and spatial distribution of the pollutant and the law of release from sediment in Taihu Lake. Acta Scientiae Circumstantiae, 2005, 25(3): 300-306. [李一平, 逢勇, 向军. 太湖水质时空分布特征及内源释放规律研究. 环境科学学报, 2005, 25(3): 300-306.]

[ 7 ] Xu Zhibo, Lu Xin, Hu Weiping et al. Release characteristics of nutrient from sediment in the estuary driven by winds and waves. Advances in Water Science, 2011, (4) : 574-579. [许志波, 卢信, 胡维平等. 风浪作用下人湖河口内源释放特 征. 水科学进展, 2011, (4): 574-579.]

[ 8 ] Zheng Youkun, Liu Kai, Xiong Zijun et al. Effect of large-scale planting water hyacinth on cultivable bacterial community 
structure in the eutrophic lake. Microbiology China, 2015, 42(1): 42-53. [郑有坤, 刘凯, 熊子君等. 大水面放养水葫 芦对富营养化湖泊水体可培养细菌群落结构的影响. 微生物学通报, 2015, 42(1): 42-53]

[ 9 ] Yong L, Wang Y, Hu S et al. Quantitative evaluation of lake eutrophication responses under alternative water diversion scenarios: A water quality modeling based statistical analysis approach. Science of the Total Environment, 2013, 468/469 (Complete) : 219-227.

[10] Shen Z, Qiu J, Hong Q et al. Simulation of spatial and temporal distributions of non-point source pollution load in the Three Gorges Reservoir Region. Science of the Total Environment, 2014, 493: 138-146.

[11] Tanka T, Sato T, Watanabe K et al. Irrigation system and land use effect on surface water quality in river, at Lake Dianchi, Yunnan, China. Journal of Environmental Sciences, 2013, 25(6) : 1107-1116.

[12] Cosme N, Koski M, Hauschild MZ et al. Exposure factors for marine eutrophication impacts assessment based on a mechanistic biological model. Ecological Modelling, 2015, 317: 50-63.

[13] Yu Q, Wang HZ, Li Y et al. Effects of high nitrogen concentrations on the growth of submersed macrophytes at moderate phosphorus concentrations. Water Research, 2015, 83: 385-395.

[14] Mciver R, Milewski I, Lotze HK. Land use and nitrogen loading in seven estuaries along the southern Gulf of St. Lawrence, Canada. Estuarine Coastal \& Shelf Science, 2015, 165: 137-148.

[15] Bateganya NL, Mentler A, Langeraber G et al. Carbon and nitrogen gaseous fluxes from subsurface flow wetland buffer strips at mesocosm scale in East Africa. Ecological Engineering, 2015, 85: 173-184.

[16] Tohru S, Hirofumi I, Etsuji D. Benthic nutrient remineralization and oxygen consumption in the coastal area of Hiroshima Bay. Water Research, 1989, 23(2): 219-228.

[17] Zhao Lingyu, Yang Hao, Wang Yanhua et al. Heavy metal distribution and potential ecological risks in flowers growing areas of Dounan, Yunnan. Journal of Nanjing Normal University (Natural Science Edition), 2015, (3) : 91-98. [ 赵凌宇, 杨浩, 王延华等. 云南斗南蔬菜地重金属分布及潜在生态风险评价. 南京师范大学报 (自然科学版), 2015, (3): 91-98.]

[18] Lu Haiyan, Hu Zhengyi, Zhang Ruijie et al. Spatial variability of nitrogen in soils in farmland adjacent suburban villages at northern bank of Lake Dianchi. Journal of Agro-Environment Science, 2010, (8): 1618-1623. [陆海燕, 胡正义, 张瑞 杰等. 滇池北岸居民-农田混合区域农田土壤磷素空间分布特征研究. 农业环境科学学报, 2010, (8): 1618-1623. ]

[19] Qian Jin. Reasonable analysis and afterthoughts on the construction of new district-A case study of Chenggong, Kunming. Regional Economic Review, 2014, (4) : 60-63. [ 钱津. 新区建设的理性分析与思考一一以昆明呈贡新区建设为分析 例证. 区域经济评论, 2014, (4):60-63.]

[20] Yang Xu. Afterthoughts and suggestions on the plan of green avenue in Chenggong New District, Kunming. Journal of Henan Science and Technology, 2013, (2) : 179. [杨旭. 对昆明呈贡新区绿道规划的思考与建议. 河南科技, 2013, (2) : 179.]

[21] Chen QW, Tan K, Zhu CB et al. Development and application of a two-dimensional water quality model for the Daqinghe River Mouth of the Lake Dianchi. Journal of Environmental Sciences, 2009, 21(3) : 313-318.

[22] Lu HF, Yuan YG, Campbell DE et al. Integrated water quality, emergy and economic evaluation of three bioremediation treatment systems for eutrophic water. Ecological Engineering, 2014, 69(4) : 244-254.

[23] Zhao Lei, Yang Fengle, Yuan Guolin et al. Simulation of the quantity and quality of the urban runoff. Acta Ecologica Sini$c a, 2015,(6):$ 1961-1972. [赵否, 杨逢乐, 袁国林等. 昆明市明通河流域降雨径流水量水质 SWMM 模型模拟. 生 态学报, 2015, (6): 1961-1972.]

[24] Chen Yongchun, Zhang Degang, Tang Li. The spatial and temporal variations of phosphate concentrations and their relationship with algal growth in Lake Dianchi, China. Ecology and Environmental Sciences, 2010, (6) : 1363-1368. [ 陈永 川, 张德刚, 汤利. 滇池水体磷的时空变化与藻类生长的关系. 生态环境学报, 2010, (6) : 1363-1368.]

[25] Wang Yinzhu, Zhang Wenhua, Jiang Jiahu. Primarily research about character of water current in Lake Dianchi. Transactions of Oceanology and Limnology, 1986, (1): 14-20. [王银珠, 张文华, 姜加虎. 滇池湖流特性的初步研究. 海洋 湖沼通报, 1986, (1) : 14-20.]

[26] He Jia, Chen Chunyu, Deng Weiming et al. Distribution and release characteristics of phosphorus in water-sediment interface of Lake Dianchi. J Lake Sci, 2015, 27(5) : 799-810. DOI : 10.18307/2015.0506. [何佳, 陈春瑜, 邓伟明等. 滇 
池水-沉积物界面磷形态分布及潜在释放特征. 湖泊科学, 2015, 27(5) : 799-810.]

[27] Chen Yongchuan, Tang Li, Zhang Degang et al. The Spatially and temporally dynamic variation of total phosphorus in sediment of Lake Dianchi. Journal of Agro-Environment Science, 2007, (1): 51-57. [ 陈永川, 汤利, 张德刚等. 滇池沉积 物总磷的时空分布特征研究. 农业环境科学学报, 2007, (1) : 51-57.]

[28 ] Ma Wei, Pu Chengsong, Luo Jiacui et al. Hydrodynamic characteristics of Lake Dianchi and its influence on accumulation of blue-green algae in Lake Dianchi. Journal of Hydraulic Engineering, 2013, S1: 22-27. [马巍, 浦承松, 罗佳翠等. 滇 池水动力特性及其对北岸蓝藻堆积驱动影响. 水利学报, 2013, S1: 22-27.]

[29] Li Jinxiu, Liu Shukun, Chen Xijun et al. Preliminary study on the effect of mountain sheltering on the wind-driven water current in Lake Dianchi. J Lake Sci, 1996, 8(4) : 312-318. DOI: 10.18307/1996.0404. [李锦秀, 刘树坤, 陈喜军等. 山体遮挡对滇池风生流的影响初探. 湖泊科学, 1996, 8(4) : 312-318.]

[30] Li Jianjin, Huang Yong, Li Dapeng et al. Effect of different sediment resuspension modes on particulate phosphorus bioavailability in overlying water. Environmental Science and Technology, 2012, 10: 20-24, 80. [李建金, 黄勇, 李大鹏等. 底泥不同悬浮方式对水体生物有效磷的影响. 环境科学与技术, 2012, 10: 20-24, 80.]

[31] Xing KX, Guo HC, Sun YF. Assessment of the spatial-temporal eutrophic character in the Lake Dianchi. Journal of Geographical Sciences, 2005, 15(1): 37-43.

[32] Ma Jianrong, Deng Jianming, Qin Boqiang et al. Progress and prospects on cyanobacteria bloom-forming mechanisms in lakes. Acta Ecologica Sinica, 2013, 33(10) : 3020-3030. [马健荣, 邓建明, 秦伯强等. 湖泊蓝藻水华发生机理研究 进展. 生态学报, 2013, 33(10) : 3020-3030.]

[33] Yu Dong, Li Farong, Wang Jiangtao. Water environment evolution and algae monitoring technology development in Lake Dianchi. Environmental Science Survey, 2013, (5): 53-57. [余冬, 李发荣, 王江涛. 滇池水环境演变与藻类监控技 术发展分析. 环境科学导刊, 2013, (5): 53-57.]

[34] Yuan Jingxiu, Zhang Wenhua, Wang Yinzhu. Thermal regime of Lake Dianchi. Ocranologia et Limnologia Sinica, 1986, (6)：481-492. [袁静秀, 张文华, 王银珠. 滇池的热学状况. 海洋与湖沼, 1986, (6) : 481-492.]

[35] Guo Wanxi, Hou Wenhua, Miao Jing et al. Effects of different hydrophytes on the phosphorus redistribution in plant-overlay water-sediment systems. Journal of Beijing University of Chemical Technology, 2007, (1): 1-4. [郭万喜, 侯文华, 缪 静等. 不同水生植物对系统中磷分配的影响. 北京化工大学学报(自然科学版), 2007, (1): 1-4.]

[36] Zhang Zhihong, Yu Yizun, Huang Jiangli et al. Study on the amount of main physiological bacteria and its relation with environmental factors in Poyang Lake water. Ecology and Environmental Sciences, 2015, (6) : 1037-1042. [张志红, 于一 尊, 黄江丽等. 鄱阳湖湖区主要微生物生理群数量与环境因子关系研究. 生态环境学报, 2015, (6) : 1037-1042.]

[37] Sun Gang, Sheng Lianxi. Ecological engineering for eutrophication control in lake. Chinese Journal of Applied Ecology, 2001，(4) : 590-592. [孙刚，盛连喜. 湖泊富营养化治理的生态工程. 应用生态学报, 2001，(4) : 590-592.]

[38] Wang Baisha, Yan Denghua, Zhao Zhixuan et al. Roles of constructed wetland system in lake ecological restoration. Chinese Journal of Ecology, 2010, (12) : 2514-2520. [翁白莎, 严登华, 赵志轩等. 人工湿地系统在湖泊生态修复中的 作用. 生态学杂志,2010, (12): 2514-2520.] 